\title{
sciendo
}

CIVIL AND ENVIRONMENTAL ENGINEERING REPORTS

E-ISSN 2450-8594

CEER 2021; 31 (1): 0139-0160

DOI: $10.2478 /$ ceer-2021-0010

Original Research Article

\section{THE EFFECTS OF ADDITIVES TO LIGHTWEIGHT AGGREGATE ON THE MECHANICAL PROPERTIES OF STRUCTURAL LIGHTWEIGHT AGGREGATE CONCRETE}

\author{
Mehdi KHOSHVATAN ${ }^{1}$, Majid POURAMINIA ${ }^{2}$ \\ ${ }^{1}$ Department of Civil Engineering, College of Engineering, Kermanshah Branch, Islamic Azad \\ University, Kermanshah, Iran \\ ${ }^{2}$ Department of Civil Engineering, Ramsar Branch, Islamic Azad University, Ramsar, Iran
}

\begin{abstract}
In the paper, the effects of different percentages of additives (perlite, LECA, pumice) on the mechanical properties of structural lightweight aggregate concrete were tested and evaluated. For the research, 14 mixing designs with different amounts of aggregate, water, and cement were made. Experimental results showed that the specific gravity of lightweight structural concrete made from a mixture of LECA, pumice, and perlite aggregates could be $25-30 \%$ lighter than conventional concrete. Lightweight structural concrete with a standard specific gravity can be achieved by using a combination of light LECA with perlite lightweight aggregates (LA) and pumice with perlite in concrete. The results indicated that LECA lightweight aggregates show more effective behavior in the concrete sample. Also, the amount of cement had a direct effect on increasing the strength regardless of the composition of LAs. The amount of cement causes compressive strength to increase. Furthermore, the stability of different experimental models increased from 156 to $345 \mathrm{~kg} / \mathrm{m}^{3}$ while increasing the amount of cement from 300 to $400 \mathrm{~kg} / \mathrm{m}^{3}$ in the mixing designs of LECA and perlite for $\mathrm{W} / \mathrm{C}$ ratios of $0.3,0.35$, and 0.4 . For a fixed amount of cement equal to $300 \mathrm{~kg}$, the compressive strength is reduced by $4 \%$ by changing the water to cement ratio from 0.5 to 0.4 . The compression ratios of strength for 7 to 28 days obtained in this study for lightweight concrete were between $0.67-0.8$. Based on the
\end{abstract}

${ }^{2}$ Corresponding Author: Ramsar Branch, Islamic Azad University, Assistant Professor, Majid Pouraminian, E-mail: m.pouraminian@iauramsar.ac.ir 
rate of tensile strength to compressive strength of ordinary concretes, which is approximately 10 , this ratio is about 13.5 to-17.8 in selected and optimal lightweight concretes in this research, which can be considered good indirect tensile strength for structural lightweight concretes.

Keywords: structural lightweight concrete, perlite, LECA, pumice, mechanical properties

\section{INTRODUCTION}

In recent years, many experts have studied the durability of reinforced concrete structures, especially in corrosive areas, and most concluded that strength alone cannot meet all the required properties of concrete, especially its durability. In designing concrete for different applications, its reliability and durability should be considered in addition to the strength and load-bearing requirements during its operation. The use of lightweight natural and artificial materials is considered an effective solution for reducing the dimensions of the structure and minimizing the seismic force acting on the concrete, ultimately increasing the speed of implementation and reducing costs.

Khaloo (1994) used industrial waste as coarse aggregate in concrete; three types of clinker bricks were crushed from 13 clinker brick manufacturers and then tested for grading, unit weight, water absorption, and abrasion resistance. The results were compared with those of ordinary crushed stone materials. Their research included experiments on concrete cylinders under uniaxial compression and splitting tension, and concrete beams under ductility[9]. Aydın and Baradan (2007) concluded that thermal stability is an essential factor in selecting materials for high heat, and the lightweight concrete should have low thermal conductivity for increased resistance against fire. They concluded that an important feature of lightweight structural concrete compared to normal concrete is the fire resistance factor [4]. Khaloo et al. (2008) evaluated the possibilities of using particles and flexible rubber as aggregates in concrete. The width of a crack and its progression rate in rubber concrete is less than in standard concrete[10]. Zaetang et al. (2013) examined light and heavy recycled concrete and reported that recycled concrete has less compressive strength [12]. Bogas et al. (2013) evaluated the compressive strength of structural-lightweight-concrete using non-destructive ultrasonic pulse velocity [6]. Approximately 84 different compounds were tested, and results indicated that normal and lightweight concretes are affected by mixture parameters. Some studies have also shown that lightweight structural concrete can be used for construction purposes as insulation, Nguyen et al. (2014)[13].

The experimental results indicated that adding steel fibers greatly improves the flexural-strength, tensile-strength, and stroke resistance of concrete models, and adding steel fibers has little effect on the compressive strength, Huang et al. 


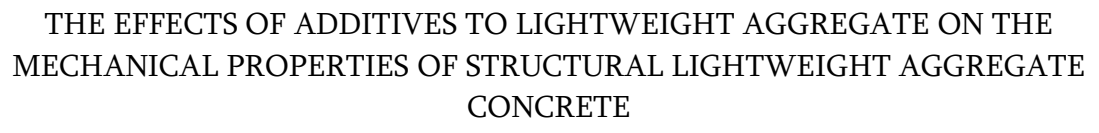

(2013)[7]. Shafigh et al. (2012) used Palm Oil Boiler Clinker, solid waste from the palm oil industry; supersede aggregate in the making of environmentally friendly structural lightweight concrete[11]. Yu et al. (2015) The available studies on lightweight concrete indicate significant variations in mechanical and thermal properties under the influence of ingredients and mixing ratios[15]. Bogas and Gomes (2015) evaluated the mechanical behavior and long-term durability of structural lightweight concrete produced with natural scoria aggregate. They concluded that long-term contraction increased by replacing the total normal weight with LWA, which was higher when they used coarse and fine scoria. The LWC with scoria can be stable and medium-resistance LWCs carbonationinduced corrosion may not be associated[5]. Shafigh et al. (2018) compared the characteristics of the normal weight of concrete with fresh and hardened lightweight concrete. Their results showed that LECA concrete indicates more drying. The contraction from normal weight and lightweight OPBC decreased between 14 and 90 days. They reported that OPBC concrete can be used in constructing green concrete and agricultural industries[16]. Wongkvanklom et al. (2018) examined lightweight structural concrete with recycled lightweight concrete and reported that SLC was obtained with a satisfactory compressive strength of 28days between about 16 to $30 \mathrm{MPa}$, and density was between 1600-1800 $\mathrm{kg} / \mathrm{m} 3$ [17]. Aghamohammadzadeh et al. (2019) experimentally evaluated the relationship between shear deformation in lightweight reinforced concrete beams. The flexural and shear behaviors of lightweight reinforced concrete beams and their connection to a column were investigated experimentally[18]; Tajra Et al. (2019) examined the specification of lightweight concrete to shell aggregate in the concrete core. Lightweight structural shell aggregates (CSAs) were produced through cold bonding by encapsulating an expanded perlite particle (as a nuclear structure) into a shell matrix consisting of cement, fly ash, and developed perlite powder. The effect of different sintering regimes on the mechanical and microstructural properties of the CSA was studied. The properties of lightweight concrete made of CSA or expanded clay aggregate (ECA) were closely compared in terms of their potential economic and environmental benefits in response to the high energy consumption associated with ECA production. The results showed that cooking at $99 \%$ relative humidity is the most suitable cooking method for CSA[20]. Regin et al. (2019) investigated the ability of a neural network to predict the compressive strength of lightweight concrete with coconut shell. Optimal compressive strength is obtained for $10 \%$ of the sample with silica foam and 28 day compressive strength of concrete with replacement of silica foam and fly ash meets the minimum requirements for lightweight structural concrete using MATLAB and consists of seven inputs and one output. One hundred and sixtyeight experimental data were used to develop a multilayer feeding neural network 
model back and forth. The average square error for the predicted values according to the test value is 0.0348 . The predicted compressive strength was compared with the experimental resistance and they were significantly closer to each other[22]. Demirel et al. (2019) tested the performance of lightweight structural concrete containing metakaolin in the next stage after temperature increase. The two variables were defined as increasing the temperature of $20,400,600$, and $800^{\circ} \mathrm{C}$ and the ratio of metakaolin to cement of $0 \%, 5 \%, 11 \%, 18 \%$, and $25 \%$, and the compressive strength of lightweight structural concrete. The effects of each variable on the response That compressive strength is determined after ANOVA analysis (change analysis) and developed the model equation[21]. Bogas et al. (2019) looked at the effect of cracking on capillary adsorption and carbonation of lightweight structural concrete. Their results show that when LWAC was subjected to natural cracking, there was greater participation of more porous aggregates[19]. Yu et al. (2020) studied the effect of expanded hydrophobic silicate grains on the behavior of structural lightweight concrete. The results of their research showed that the concretes they made have an entirely compact microstructure and contribute to greater strength. Their mixes showed excellent durability, with shallow water penetration after $72 \mathrm{~h}$ of exposure under a pressure of $0.5 \mathrm{MPa}$ ( 5 bar) and shallow mass loss after 56 freezing-thawing periods. Both conditions were subjected to non-deionized water[23]. Shariati et al. (2020) developed a new artificial intelligence model for compressive strength simulating lightweight silica concrete. They proposed a self-consistent, formula-based model called Splines optimized multivariate adaptive regression using the water cycle algorithm (MARS-WCA) for fc modeling based on mixed ratios. 418 experimental datasets were collected from open-source literature for calibration and validation of computational intelligence models. The best subset regression method based on different forms of compounds using the Mallow coefficient to determine the useful variables affecting fc lightweight cellular concrete (FCLC)[27]. Kalpana and Tayu (2020) conducted an experimental study of lightweight concrete with added industrial steel scrap. Compression tests, flexural tests, and tensile tests were performed to evaluate the mechanical properties of 28 day perlite lightweight concrete with $0.5 \%$ and $1 \%$ steel scrap added to the mixture. The results showed a significant improvement in the tensile and flexural properties of perlite lightweight concrete. Compressive strength increases at $0.5 \%$ but slightly decreases at $1 \%$ compared to perlite lightweight concrete without added steel scrap[26].

Sikora et al. (2020) evaluated the effects of nano-silica on the properties of light and ultra-lightweight concrete materials using image-based approaches. Their results showed that nano-silica has a significant effect on improving the mechanical properties and transport of lightweight concrete, and the efficiency of nano-silica effects is much higher than silica foam. Depending on the amount 


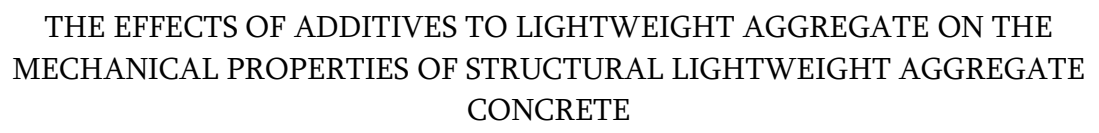

used, it was found that nano-silica after 28 days of curing has little or no effect on concrete shrinkage[25]. Ibrahim et al. (2020) investigated the durability of lightweight structural concrete containing expanded perlite aggregate. Their results showed that the unit weight of concrete is reduced by 20 to $30 \%$ compared to concrete with normal weight. The compressive strength of the samples tested showed that they are sufficient for use as structural concrete, especially mixtures containing $10 \%$ and $15 \%$ perlite aggregates. The durability of LWC is comparable to NWC in terms of the chloride emission and concrete corrosion resistance of reinforcing steel[24]. Salim (2020) studied the effect of fracture of artificial materials and the permeability of the concrete illustrates how the use of volcanic ash aggregates and synthetic slag materials affects the functional properties of concrete[14]. Oghabi and Khoshvatan (2020) studied the effect of the amount and length of plastic fibers on the compressive and tensile strength of SCC. They examined 13 concrete mixing designs with a w/c ratio of 0.4 . They selected 1 fiber-free design as a reference model and made 12 self-compacting concrete designs containing plastic fibers with dimensions of 1,2 , and $3 \mathrm{~cm}$ and 100, 250, 500, and $1000 \mathrm{gr} / \mathrm{m}^{3}$ in the laboratory. Based on the experimental results, increasing the amount and length of the fibers leads to a decrease in flowability and permeability and a sign cant, increasing the splitting strength in the model. The compressive strength increased by about 8 percent and the tensile strength by about 22 percent after adding plastic fibers, with this increase depending more on the number of fibers, whereas changing the length of the fibers did not have much effect[28]. Yang (2021) studied the shear friction response of lightweight concrete using floor ash aggregates and air foams. Experimental and analytical results showed that the addition of air foam slightly reduces the friction angle of integrated interfaces but has little effect on smooth structural joints. Therefore, the effect of air foam up to $20 \%$ by volume on the cohesion and friction angle of concrete is marginal[29].

Natalli et al. (2021) introduced a new method for the analysis of steel-concrete bonds in CFST filled with light and ordinary concrete. The results showed that the low modulus of elasticity of lightweight concrete helps to increase the trapping and microblock effect, and the extensive additive improves the adhesion performance of the filler core. Also, the new method communicates well with other tests and is easy to use[30].

\section{EXPERIMENTAL PROCEDURE}

\subsection{Material}

The aggregates used in this research consisted of sand passed through a $12.5 \mathrm{~mm}$ sieve and residue on a $0.5 \mathrm{~mm}$ sieve. The density of aggregates according to the 
experiments was $2560 \mathrm{~kg} / \mathrm{m}^{3}$. Table 1 shows the chemical analysis of cement type and comparison with the existing standard. Table 2 shows the chemical analysis of micro-silica used in the present study.

Table 1. Results of chemical analysis of type two standard cement and cement used in the present study

\begin{tabular}{|l|c|c|c|c|c|c|c|c|c|c|c|c|c|c|}
\hline $\begin{array}{l}\text { Chemical } \\
\text { Mixture }\end{array}$ & $\mathrm{CaO}$ & $\mathrm{SiO}_{2}$ & $\mathrm{Al}_{2} \mathrm{O}_{3}$ & $\mathrm{Fe}_{2} \mathrm{O}_{3}$ & $\mathrm{MgO}$ & $\mathrm{K}_{2} \mathrm{O}$ & $\mathrm{Na}_{2} \mathrm{O}$ & $\mathrm{sO}$ & $\mathrm{Cl}$ & $\mathrm{C}_{4} \mathrm{AF}$ & $\mathrm{C}_{3} \mathrm{~A}$ & $\mathrm{C}_{3} \mathrm{~S}$ & $\mathrm{C}_{2} \mathrm{~S}$ & All \\
\hline $\begin{array}{l}\text { Standard } \\
\text { value }\end{array}$ & 63 & 21 & 5 & 4 & 2 & 0.6 & 0.5 & 2 & 0.05 & 9 & 6.5 & 55 & 17.5 & 186.1 \\
\hline $\begin{array}{l}\text { present } \\
\text { study }\end{array}$ & 64 & 22 & 4.7 & 3.5 & 2 & 0.85 & 0.35 & 2.5 & 0.001 & 9 & 7 & 56 & 15 & 186.9 \\
\hline
\end{tabular}

Table 2. Results of chemical analysis of micro-silica used in the present study

\begin{tabular}{|c|l|l|l|l|l|l|l|l|l|l|}
\hline Chemical Mixture & $\mathrm{SiO}_{2}$ & $\mathrm{Al}_{2} \mathrm{O}_{3}$ & $\mathrm{~K}_{2} \mathrm{O}_{3}$ & $\mathrm{MgO}$ & $\mathrm{SiC}$ & $\mathrm{Na}_{2} \mathrm{O}$ & $\mathrm{Fe}_{2} \mathrm{O}_{3}$ & $\mathrm{C}$ & $\mathrm{P}_{2} \mathrm{O}_{5}$ & $\mathrm{SO}_{3}$ \\
\hline $\begin{array}{c}\text { Percentage of } \\
\text { ingredient }\end{array}$ & 94 & 1.3 & 1 & 0.95 & 0.5 & 0.32 & 0.3 & 0.3 & 0.15 & 0.1 \\
\hline
\end{tabular}

In this research, in order to achieve a higher amount of solidity, a mixture of two volumes of fine-grained perlite and a volume of coarse-grained perlite and LECA was used in the concrete mixing design. The density of used perlite varied according to experiments in a range of $32-400 \mathrm{~kg} / \mathrm{m}^{3}$.

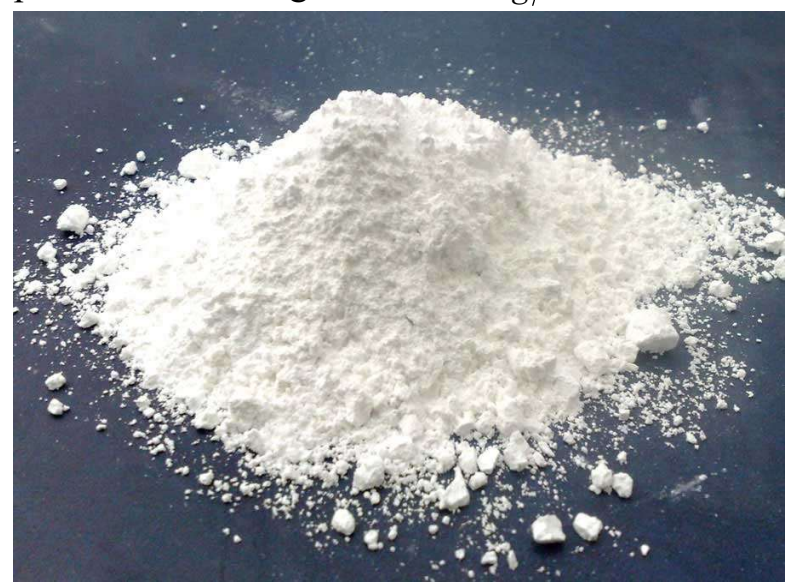

Fig. 1. Rock powder used in this research

The coarse-grained perlite was of a 3-5 mm diameter and fine-grained perlite, 1$3 \mathrm{~mm}$ diameter. $5 \%$ rock powder was used to reduce air bubbles in the concrete samples. Figure 1 shows the rock powder used in the present study. Figure 2 shows the LECA, pumice, and perlite used in this study. 


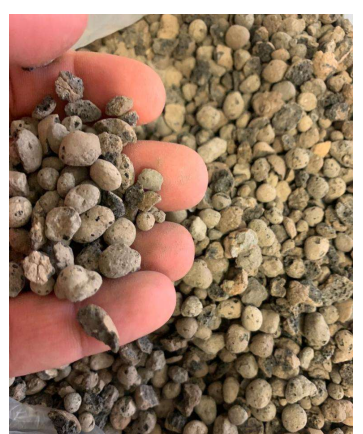

a)LECA

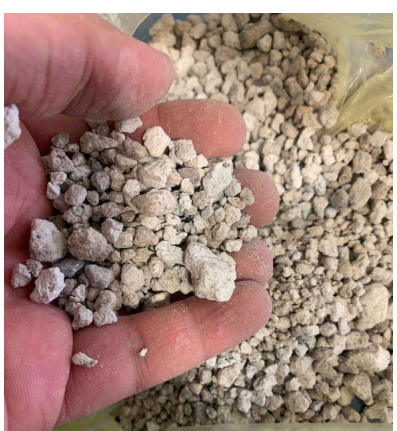

b) Pumice

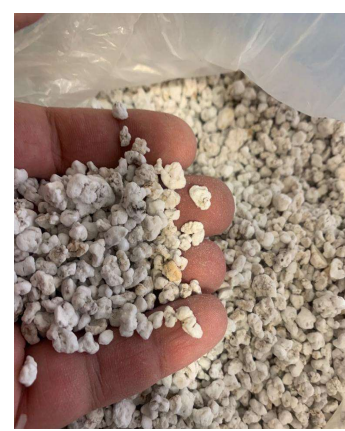

c)Perlite

Fig. 2. LECA, pumice, and perlite used in this research

\subsection{Mixing design}

Table 3. gives the mixing designs of perlite, LECA, and mineral pumice. The water to cement ratios were considered as $0.3,0.35$, and 0.4 . The amount of perlite and LECA used in the concrete models varied according to the percentage. The weight of perlite and LECA varied from 244 to 368, and cement amounts of 350$400 \mathrm{~kg}$ were used in the models.

Table 3. Mixing designs with a combination of perlite, LECA, and pumice

\begin{tabular}{|c|c|c|c|c|c|c|c|c|c|c|}
\hline No. & W/C & $\begin{array}{c}\text { Perlite and } \\
\text { LECA (\%) }\end{array}$ & $\begin{array}{c}\text { Perlite } \\
\text { and } \\
\text { LECA } \\
(\mathrm{kg})\end{array}$ & $\begin{array}{c}\text { Cement } \\
(\mathrm{kg})\end{array}$ & $\begin{array}{c}\text { Water } \\
(\mathrm{kg})\end{array}$ & $\begin{array}{c}\text { Natural } \\
\text { sand } \\
(\mathrm{kg})\end{array}$ & $\begin{array}{c}\text { Gravel } \\
(\mathrm{kg})\end{array}$ & $\begin{array}{c}\text { Super } \\
\text { Plasti } \\
\text { cizer } \\
(\mathrm{kg})\end{array}$ & $\begin{array}{c}\text { Micro } \\
\text { silica } \\
(\mathrm{kg})\end{array}$ & $\begin{array}{c}\text { Rock } \\
\text { flour } \\
(\mathrm{kg})\end{array}$ \\
\hline 1 & 0.35 & $\begin{array}{c}\text { Reference } \\
\text { model }\end{array}$ & - & 400 & 140 & 900 & 900 & 9 & 40 & - \\
\hline 2 & 0.3 & $\begin{array}{c}\text { Perlite 15\%+ } \\
\text { LECA 40\% }\end{array}$ & 311.2 & 350 & 105 & 600 & 370 & 8 & 0.35 & 58 \\
\hline 3 & 0.3 & $\begin{array}{c}\text { Perlite 10\%+ } \\
\text { LECA 50\% }\end{array}$ & 368.6 & 350 & 105 & 525 & 370 & 8 & 35 & 58 \\
\hline 4 & 0.35 & $\begin{array}{c}\text { Perlite 15\%+ } \\
\text { LECA 40\% }\end{array}$ & 302.9 & 350 & 122.5 & 585 & 360 & 8 & 35 & 56 \\
\hline 5 & 0.35 & $\begin{array}{c}\text { Perlite 10\%+ } \\
\text { LECA 50\% }\end{array}$ & 358.9 & 350 & 122.5 & 510 & 360 & 8 & 35 & 56 \\
\hline 6 & 0.3 & $\begin{array}{c}\text { Perlite 15\%+ } \\
\text { LECA 40\% }\end{array}$ & 295.8 & 400 & 120 & 570 & 350 & 9 & 40 & 55 \\
\hline 7 & 0.3 & $\begin{array}{c}\text { Perlite 10\%+ } \\
\text { LECA 50\% }\end{array}$ & 350.5 & 400 & 120 & 500 & 350 & 9 & 40 & 55 \\
\hline 8 & 0.35 & $\begin{array}{c}\text { Perlite 15\%+ } \\
\text { LECA 40\% }\end{array}$ & 268.3 & 400 & 140 & 550 & 340 & 9 & 40 & 53 \\
\hline 9 & 0.35 & $\begin{array}{c}\text { Perlite 10\%+ } \\
\text { LECA 50\% }\end{array}$ & 339 & 400 & 140 & 485 & 340 & 9 & 0.4 & 53 \\
\hline 10 & 0.4 & $\begin{array}{c}\text { Perlite 15\%+ } \\
\text { LECA 40\% }\end{array}$ & 245.3 & 400 & 160 & 535 & 330 & 9 & 40 & 51 \\
\hline 11 & 0.3 & $\begin{array}{c}\text { Perlite 15\%+ } \\
\text { LECA 40\% }\end{array}$ & 521.9 & 400 & 120 & 570 & 350 & 9 & 40 & 55 \\
\hline 12 & 0.3 & $\begin{array}{c}\text { Perlite 10\%+ } \\
\text { LECA 50\% }\end{array}$ & 295.3 & 400 & 120 & 498 & 350 & 9 & 40 & 55 \\
\hline 13 & 0.35 & $\begin{array}{c}\text { Perlite 15\%+ } \\
\text { LECA 40\% }\end{array}$ & 243.8 & 400 & 140 & 551 & 340 & 9 & 40 & 53 \\
\hline
\end{tabular}




\section{RESULTS}

In this study, 14 different mixing designs with reference models and samples with LECA and perlite light aggregates were tested and evaluated. The behavioral results of different samples with light aggregates are given below.

\subsection{The results of compressive strength and indirect tensile strength}

Hardened concrete tests include compressive and tensile strength tests and tests of elastic modulus[1]. Table 4 . gives the results of the elastic modulus test of perlite and LECA mixtures.

Table 4. Results of the elastic modulus test of perlite and LECA mixtures

\begin{tabular}{|l|c|c|c|c|c|c|c|c|c|c|c|c|c|c|}
\hline No. & 1 & 2 & 3 & 4 & 5 & 6 & 7 & 8 & 9 & 10 & 11 & 12 & 13 & 14 \\
\hline$E_{\mathrm{C} \mathrm{kg} / \mathrm{cm}^{2}\left(\times 10^{5}\right)}$ & 2 & 1.5 & 1.55 & 1.4 & 1.6 & 1.83 & 1.8 & 1.77 & 1.8 & 1.68 & 1.7 & 1.5 & 1.43 & 1.4 \\
\hline
\end{tabular}

Table 5. shows the results of compressive and tensile strength tests of cylindrical models of optimal mixing designs. As aforementioned, the water to cement ratio was selected from $0.3,0.35$, and 0.4 . The results of compressive strengths of 3,7 , and 28 days are given for different models. The compressive strength, tensile strength, and tensile strength caused by flexure for 28 days are shown in different models. Figure 3. shows the deformation of other loaded models.

Table 5. Results of compressive and tensile strength tests of cylindrical models of optimal mixing designs

\begin{tabular}{|c|c|c|c|c|c|c|c|c|}
\hline No. & $(\mathrm{w} / \mathrm{c})$ & $\begin{array}{c}\text { Specific } \\
\text { gravity } \\
\text { cured } \\
\left(\mathrm{kg} / \mathrm{cm}^{2}\right)\end{array}$ & $\begin{array}{c}\text { Specific } \\
\text { gravity dried } \\
\left(\mathrm{kg} / \mathrm{cm}^{2}\right)\end{array}$ & $\begin{array}{c}3 \text { days } \\
\text { compress-ive } \\
\text { strength } \\
\left(\mathrm{kg} / \mathrm{cm}^{2}\right)\end{array}$ & $\begin{array}{c}7 \text { days } \\
\text { compress-ive } \\
\text { strength } \\
\left(\mathrm{kg} / \mathrm{cm}^{2}\right)\end{array}$ & $\begin{array}{c}28 \text { days } \\
\text { compress- } \\
\text { ive } \\
\text { strength } \\
\left(\mathrm{kg} / \mathrm{cm}^{2}\right)\end{array}$ & $\begin{array}{c}\text { Indirect } \\
\text { tensile } \\
\text { strength } \\
\left(\mathrm{kg} / \mathrm{cm}^{2}\right)\end{array}$ & $\begin{array}{c}\text { Tensile } \\
\text { strength due to } \\
\text { flexure } \\
\left(\mathrm{kg} / \mathrm{cm}^{2}\right)\end{array}$ \\
\hline 1 & 0.3 & 2500 & 2405 & 350 & 425 & 508 & 45.80 & 66.40 \\
\hline 2 & 0.3 & 1810 & 1710 & 127 & 155 & 198 & 32.45 & 40.70 \\
\hline 3 & 0.3 & 1806 & 1678 & 110 & 150 & 188 & 23.60 & 39.70 \\
\hline 4 & 0.35 & 1790 & 1688 & 112 & 143 & 182 & 31.15 & 39.10 \\
\hline 5 & 0.35 & 1775 & 1642 & 105 & 145 & 180 & 30.90 & 38.80 \\
\hline 6 & 0.3 & 1845 & 1645 & 134 & 220 & 280 & 38.00 & 47.00 \\
\hline 7 & 0.3 & 1825 & 1715 & 130 & 205 & 273 & 37.00 & 46.50 \\
\hline 8 & 0.35 & 1830 & 1725 & 125 & 202 & 274 & 37.10 & 46.60 \\
\hline 9 & 0.35 & 1800 & 1700 & 110 & 180 & 265 & 36.5 & 45.82 \\
\hline 10 & 0.4 & 1788 & 1665 & 115 & 190 & 255 & 36.10 & 45.35 \\
\hline 11 & 0.3 & 1755 & 1755 & 85 & 150 & 195 & 32.00 & 40.25 \\
\hline 12 & 0.3 & 1735 & 1735 & 98 & 143 & 186 & 31.40 & 39.50 \\
\hline 13 & 0.35 & 1745 & 1745 & 80 & 135 & 168 & 29.90 & 37.50 \\
\hline 14 & 0.35 & 1712 & 1712 & 70 & 127 & 160 & 29.25 & 36.75 \\
\hline
\end{tabular}




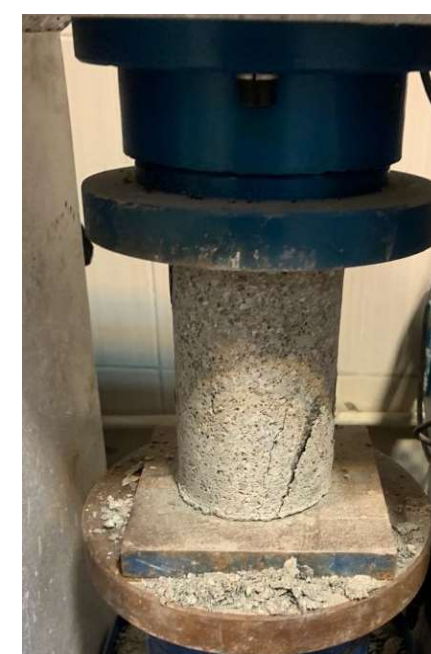

a) Reference model

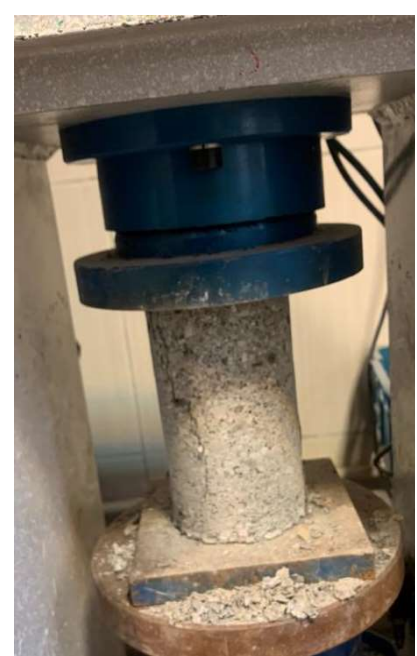

b) number 7 model Fig. 3. Sample failure

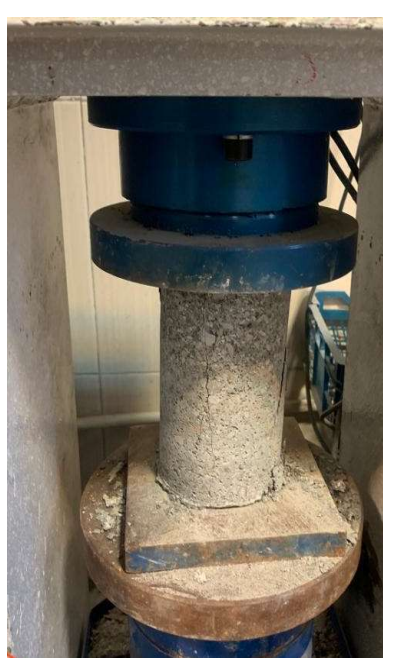

b) number 12 model

\subsection{The effect of lightweight aggregate on the compressive strength of concrete}

The compressive strength of all models made with the mixture of LAs is shown in Figures 4 and 5. The increase in compressive strength of selected lightweight concretes and the reference concrete is shown below[2-8]. The results of compressive strength of the optimal and selected designs indicated that the requirements of ASTM C 330 for the construction of lightweight structural concretes were met in all lightweight concrete mixing designs[3]. Based on the obtained results, the ratio of compressive strength of 7-days to 28-days lightweight concretes was between 0.67 and 0.81 . Considering that the ratio of tensile strength to compressive strength of ordinary concretes is about 10, this ratio in the selected and optimal lightweight concretes in this study was 13.55-17.79, which is related to the good indirect tensile strength of structural lightweight concretes. Figure 4. illustrates the results of compressive strength tests for 1 to 7 mixing designs. Figure 5. illustrates the results of compressive strength tests for 8 to 14 mixing designs. As shown, the 28-day compressive strength for model 1 is maximum. 


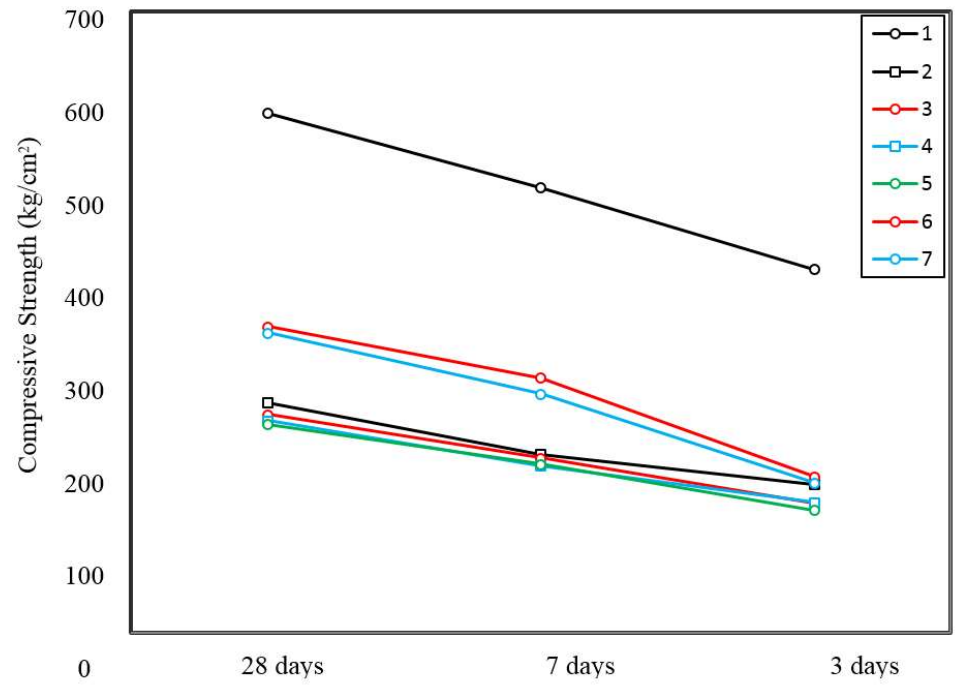

Fig. 4. Compressive strength of 1 to 7 mixing designs

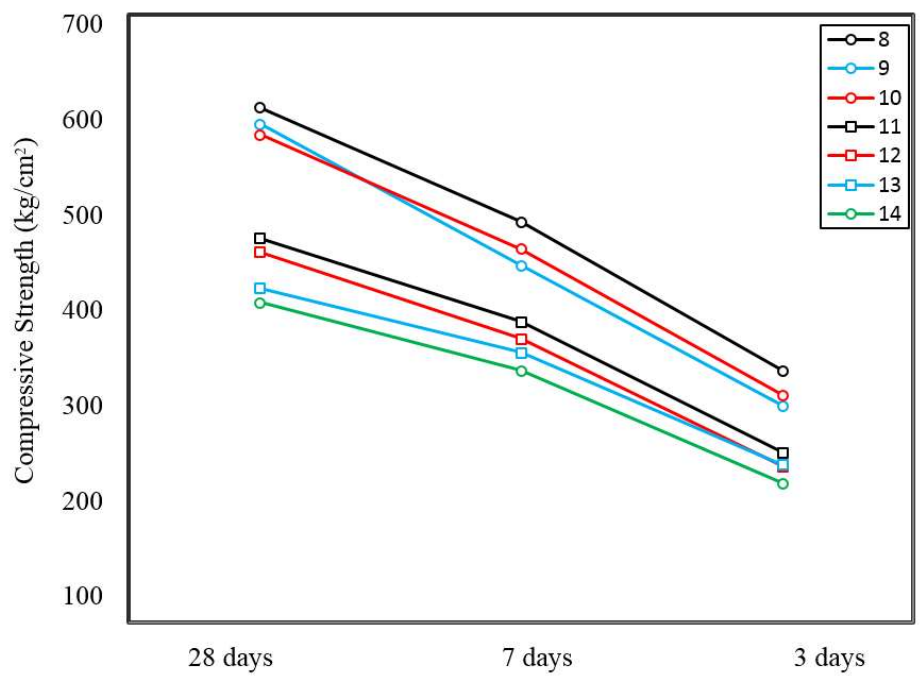

Fig. 5. Compressive strength of 8 to 14 mixing designs

Figures 6 . to 8 . show the 3,7 , and 28-day compressive strengths for thirteen lightweight concretes for optimal designs. The 14, 8, 6, 9, and 10 models were obtained. Figure 8 shows the bar diagram for the 28-day strength of models with LECA and perlite compared to pumice and perlite. As shown, the values of compressive strength for models with a mixture of LECA and perlite are higher 
THE EFFECTS OF ADDITIVES TO LIGHTWEIGHT AGGREGATE ON THE

MECHANICAL PROPERTIES OF STRUCTURAL LIGHTWEIGHT AGGREGATE CONCRETE

than the mixture of perlite and pumice. The highest compressive strength was related to model 19 with LECA and perlite.

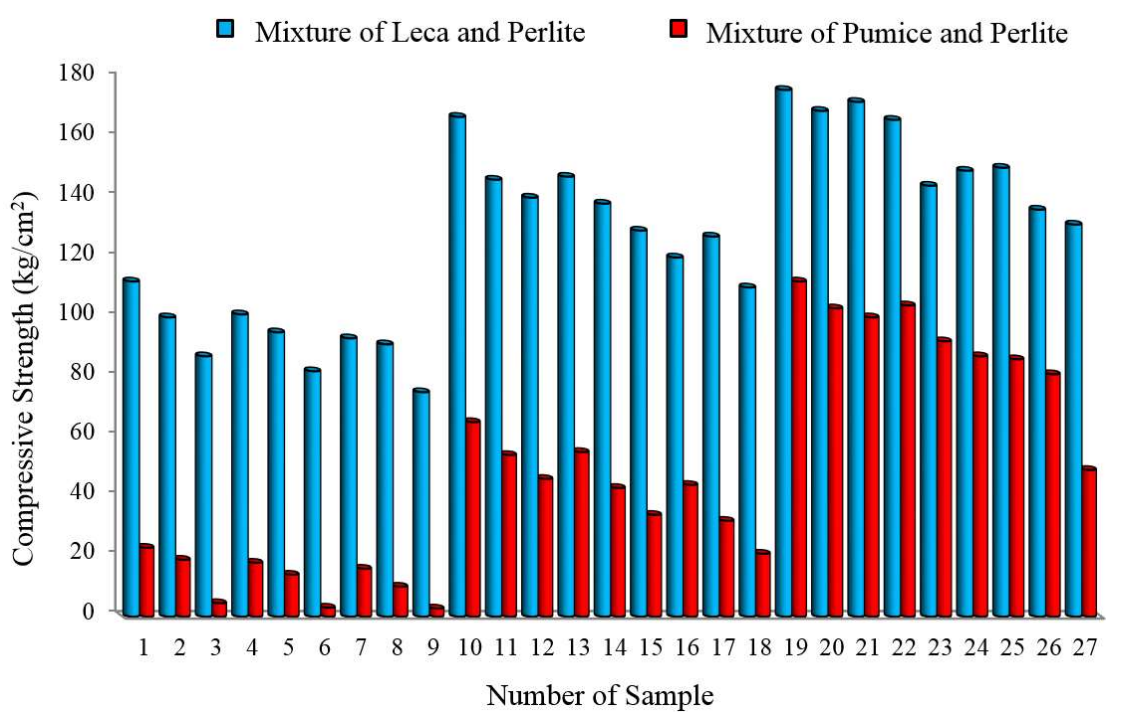

Fig. 6. The 3-day strength of models with pumice and perlite compared to LECA and perlite

c Mixture of Leca and Perlite a Mixture of Pumice and Perlite

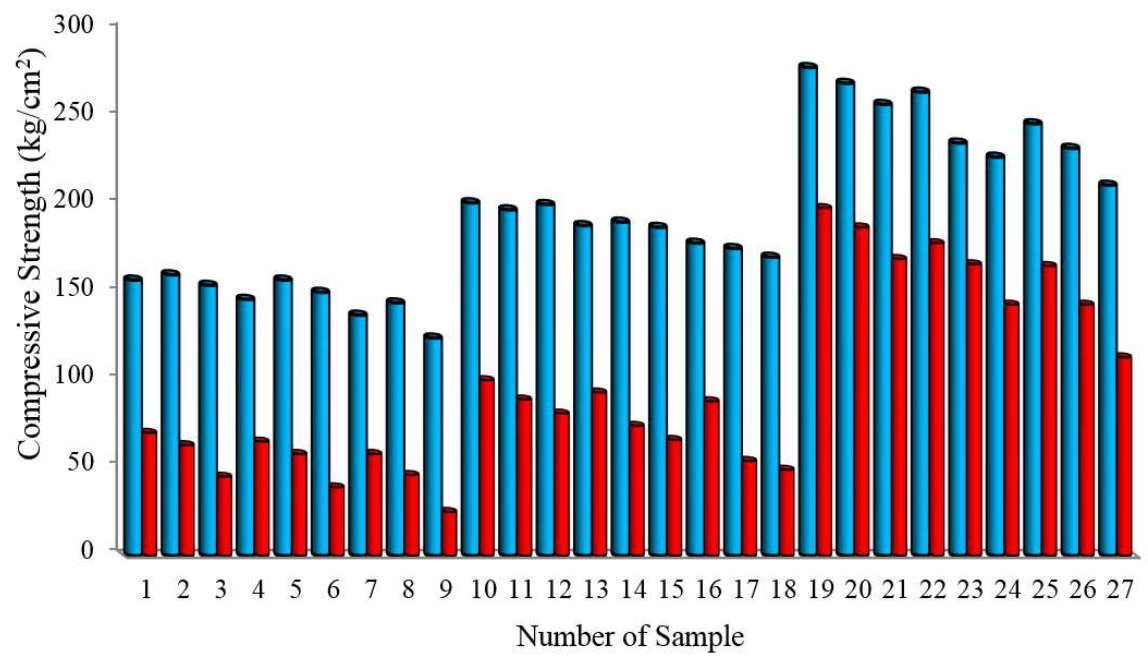

Fig. 7. The 7-day strength of models with pumice and perlite compared to LECA and perlite 


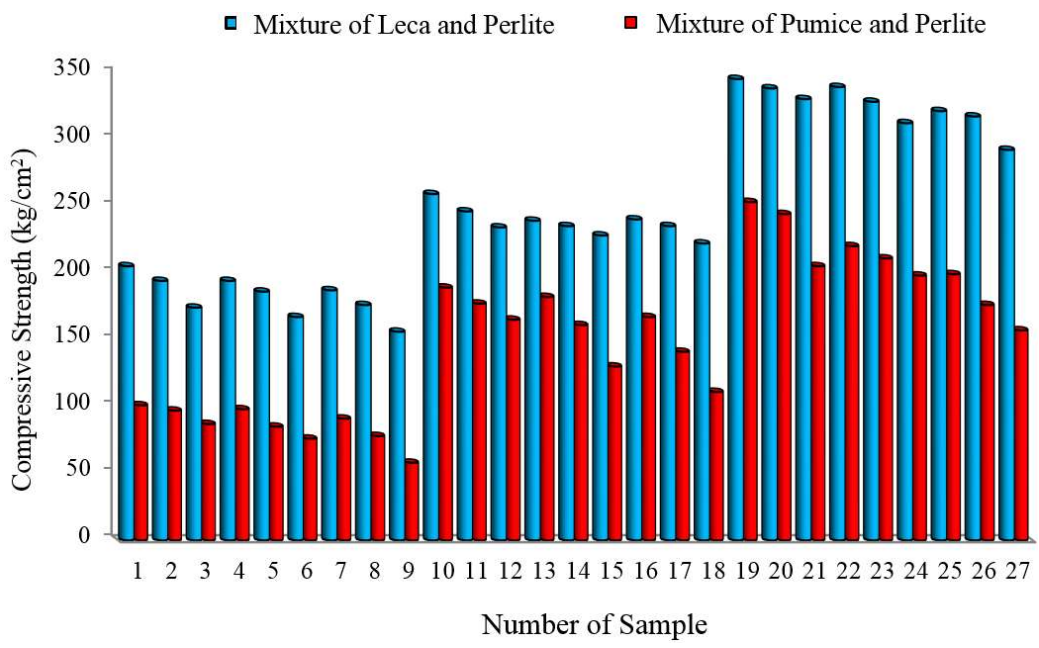

Fig. 8. The 28-day strength of models with pumice and perlite compared to LECA and perlite

\subsection{The effect of la on the specific gravity of concrete}

The results related to the impact of LA aggregate on the specific gravity of concrete are given in this section. Figure 9. shows the effect of specific gravity on the compressive strength of models with a mix of LECA and perlite and models with a mix of perlite and pumice. The compressive strength increased by increasing the specific gravity of the models for those with a mix of LECA and perlite.

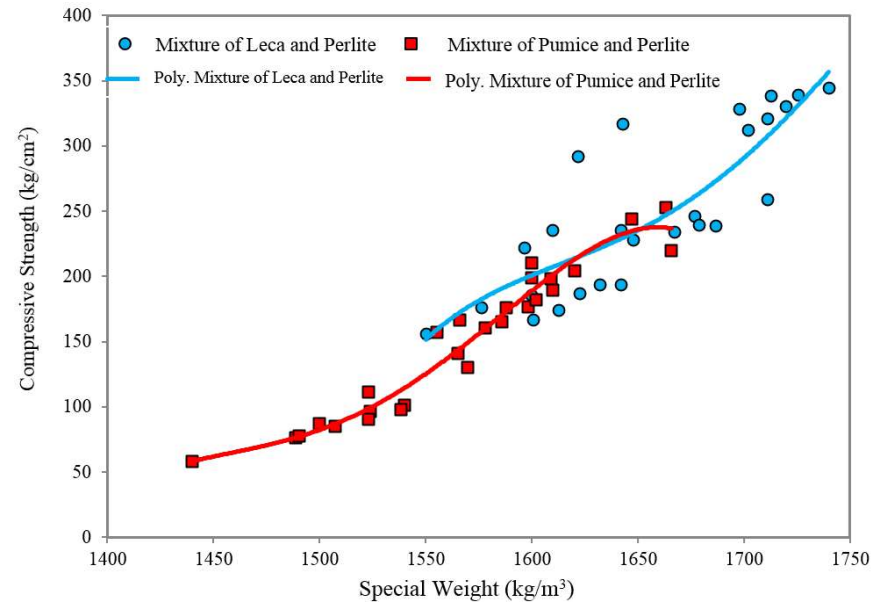

Fig. 9. The effect of specific gravity on the compressive strength 
The lowest compressive strength was obtained for models with lightweight perlite and pumice with a specific gravity of 1450 . The highest compressive strength was obtained for models with lightweight LECA and perlite aggregates and a specific gravity of about 1750. As shown, the positive and direct effect of increasing specific gravity on increasing compressive strength was confirmed.

\subsection{The effect of la on the tensile strength of concrete}

The increase of indirect tensile strength in the selected lightweight concretes is shown in Figure 10. The results indicated that the compressive strength increases by increasing specific gravity. In addition, tensile strength increased due to its relationship with compressive strength. Figure 10 displays the relationship between indirect tensile strength and the 28-day compressive strength of concrete.

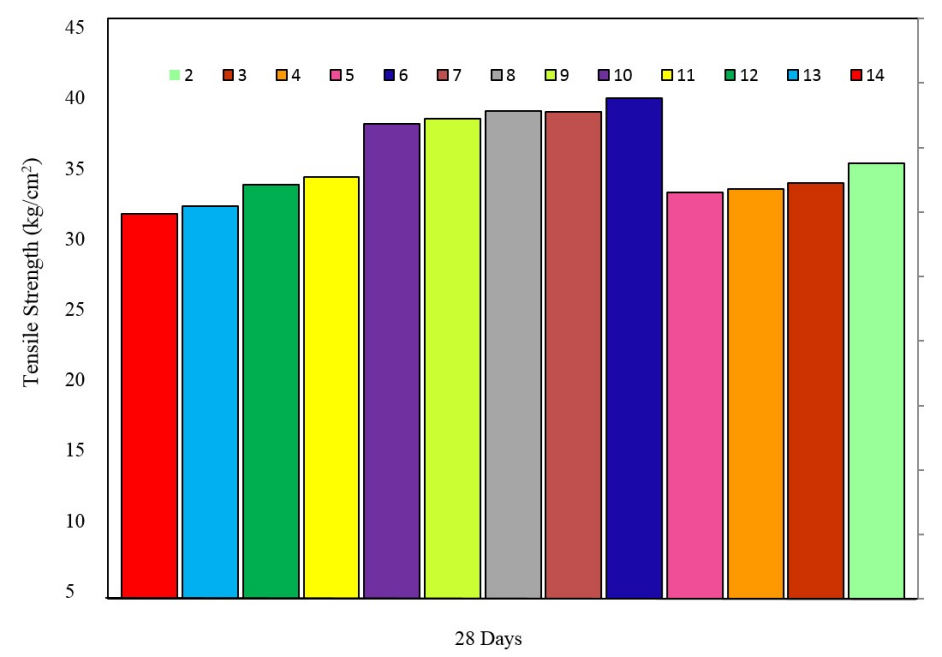

Fig. 10. Diagram of indirect tensile strength of the tested lightweight concrete models

\subsection{The effect of la on the tensile strength}

Figure 11. shows the tensile strength caused by flexure in lightweight concrete models. The effect of LA on tensile strength indicated that the highest compressive strength was obtained for model 1 , with a value of about $67 \mathrm{~kg} / \mathrm{cm}^{2}$. The lowest compressive strength was about 38 and related to model 5 .

\subsection{Evaluating the effect of cement content on compressive strength}

The experimental results showed that the compressive strength increases by increasing the amount of cement. Figure 12. illustrates that the strength of 
concretes increases from 156 to $345 \mathrm{~kg} / \mathrm{cm}^{2}$ by increasing cement from 300 to 400 $\mathrm{kg} / \mathrm{m}^{3} \mathrm{~kg} / \mathrm{m} 3$ in LECA and perlite mixing designs (group one), and with water to cement ratios of $0.3,0.35$, and 0.4. Figure 13. shows an increase in compressive strength of lightweight concrete made for both groups comparatively. As shown, the compressive strength increases in approximately equal proportions through increasing the amount of cement in all designs. Figure 13. displays the effect of increasing the amount of cement on the process of increasing the compressive strength of group one concretes.

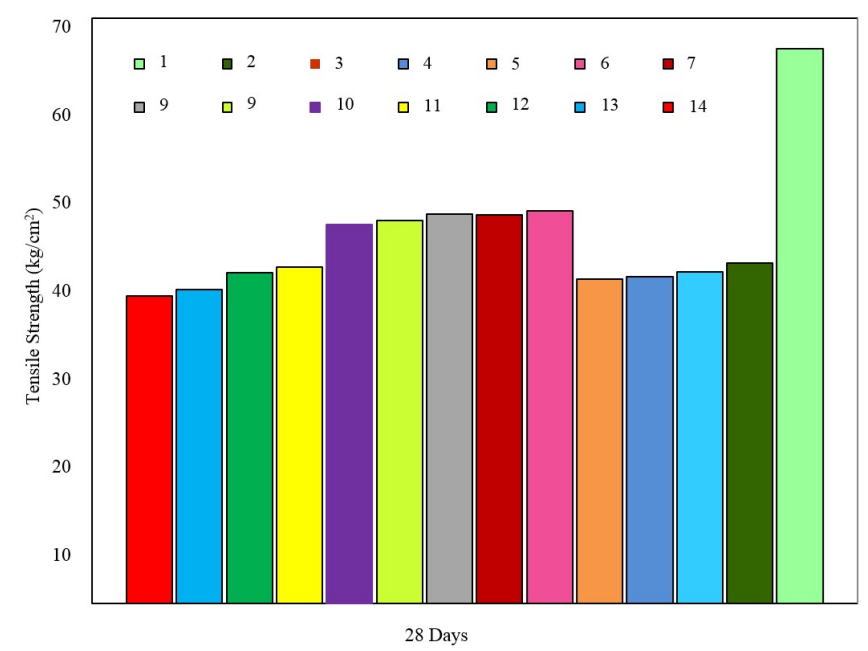

Fig. 11. Tensile strength caused by flexure in lightweight concrete models

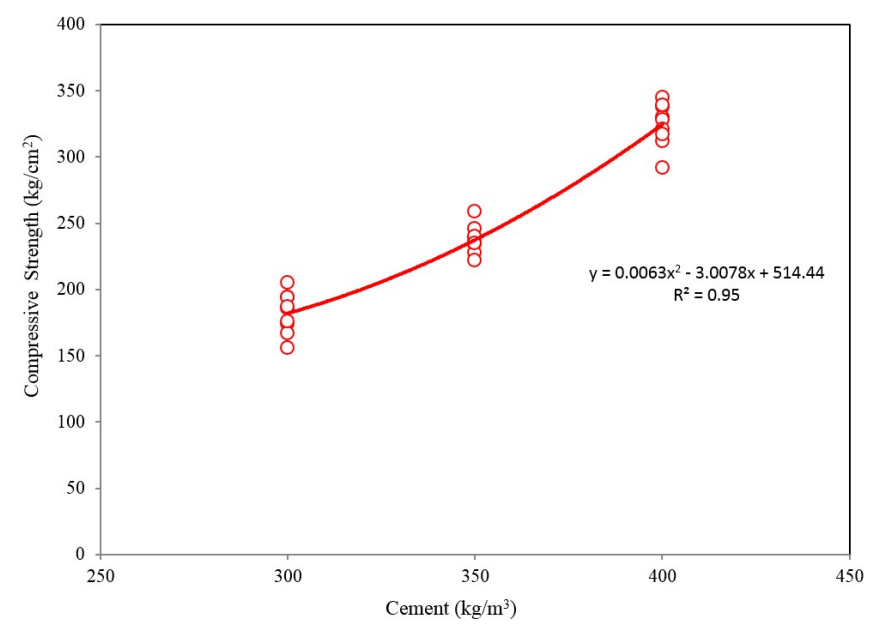

Fig. 12. Compressive strength of group one concrete with increasing the amount of cement 


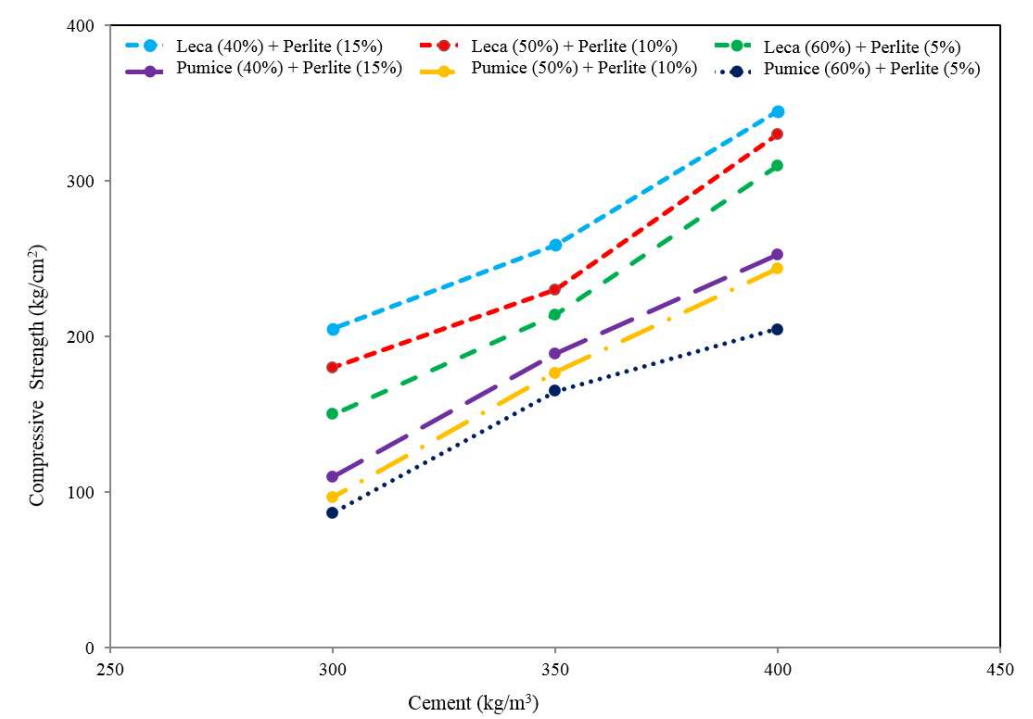

Fig. 13. The increasing trend of compressive strength with different mixtures

The effect of increasing the amount of cement on improving the compressive strength in all models used in this study is apparent. In the model with a fixed water to cement ratio of 0.3 , a mixture of $40 \%$ LECA and $15 \%$ perlite, the highest compressive strength was obtained for $400 \mathrm{~kg} / \mathrm{m} 3$ cement. The compressive strength for this model was $345 \mathrm{~kg} / \mathrm{cm}^{2}$. The minimum compressive strength (87 $\mathrm{kg} / \mathrm{m}^{3}$ ) was obtained for models with $5 \%$ perlite and $60 \%$ pumice and $300 \mathrm{~kg} / \mathrm{m}^{3}$ of cement. Figure 14. shows the increasing trend of compressive strength with different mixtures of perlite + LECA and perlite + pumice, with a water to cement ratio of 0.3 .

\subsection{The effect of w/c ratio on the compressive strength of lightweight concrete}

Figure 13. shows the compressive strength for a mixture of $40 \%$ LECA and $15 \%$ perlite in different cement contents. The compressive strength decreases when the ratio of water to cement increases. As observed, this reduction in strength is greater in concretes with a mixture of pumice and perlite aggregates than in LECA and perlite aggregates, which can be related to the absorption of more water pumice LAs. The effect of the water to cement ratio on the compressive strength of concrete with LA for the mixture of $40 \%$ LECA and $15 \%$ perlite in the water to cement ratio of 0.3 and $400 \mathrm{~kg} / \mathrm{m} 3$ of cement had the highest compressive strength $\left(345 \mathrm{~kg} / \mathrm{cm}^{2}\right)$. For cement grade 300, the compressive strength was 205 $\mathrm{kg} / \mathrm{cm} 2$ in the water to cement ratio of 0.3 and $300 \mathrm{~kg} / \mathrm{m} 3$ of consumed cement. 
Cement grade 350 demonstrated compressive strength of $259 \mathrm{~kg} / \mathrm{cm}^{2}$ in the water to cement ratio of 0.3 and $300 \mathrm{~kg} / \mathrm{m}^{3}$ of consumed cement.

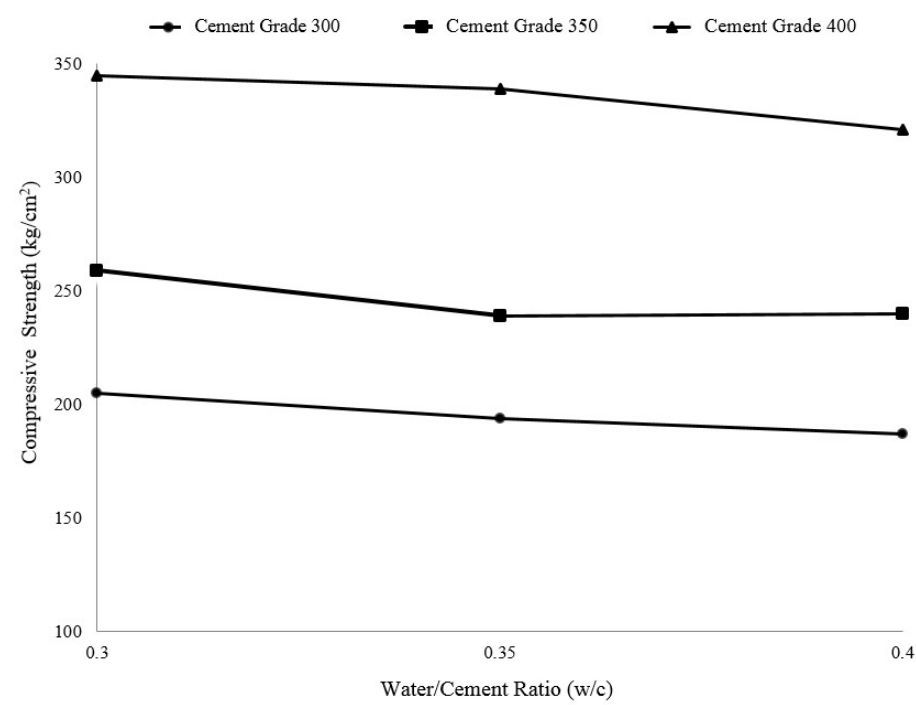

Fig. 14. Compressive strength in a mixture (LECA 40\% + perlite 15\%) in different cement grades

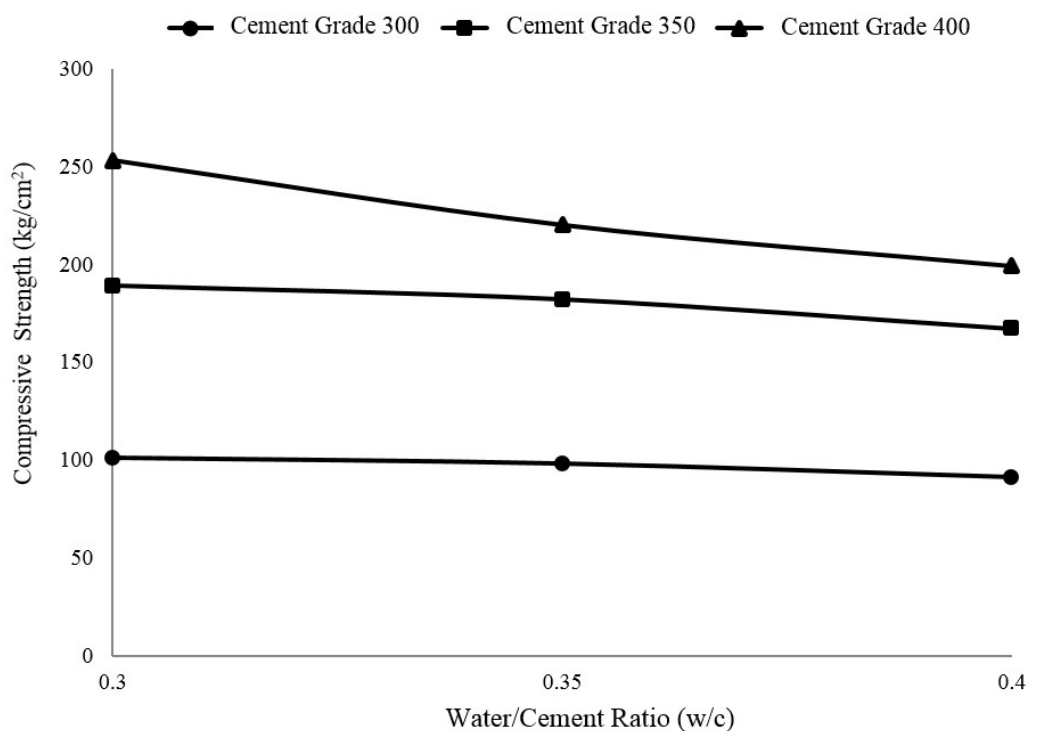

Fig. 15. Compressive strength in a mixture $(40 \%$ pumice $+15 \%$ perlite $)$ in different cement grades 
For cement grade 400 , the compressive strength was $345 \mathrm{~kg} / \mathrm{cm}^{2}$ in the water to cement ratio of 0.3 and the amount of used cement was $300 \mathrm{~kg} / \mathrm{m}^{3}$. In the model with cement grade 350, similar compressive strength values were obtained for water to cement ratios of 0.35 and 0.4 . For example, with cement grade 300 and water to cement ratio of 0.35 , the compressive strength was $194 \mathrm{~kg} / \mathrm{cm}^{2}$, and for water to cement ratio of 0.4 , the compressive strength was $187 \mathrm{~kg} / \mathrm{cm}^{2}$. It is, therefore, apparent that the compressive strength is reduced by $4 \%$ for a fixed amount of cement $(300 \mathrm{~kg})$ while changing the water to cement ratio from 0.5 to 0.4 . Figure 15 . shows the compressive strength in a mixture of $40 \%$ pumice and $15 \%$ perlite in different cement grades.

\subsection{The effect of la on the shrinkage percentage in structural lightweight concrete}

If the specific gravity of normal concrete is considered to be $2400 \mathrm{~kg} / \mathrm{m}^{3}$, the shrinkage percentage of specific gravity for the constructed lightweight concrete is shown in Figure 16.

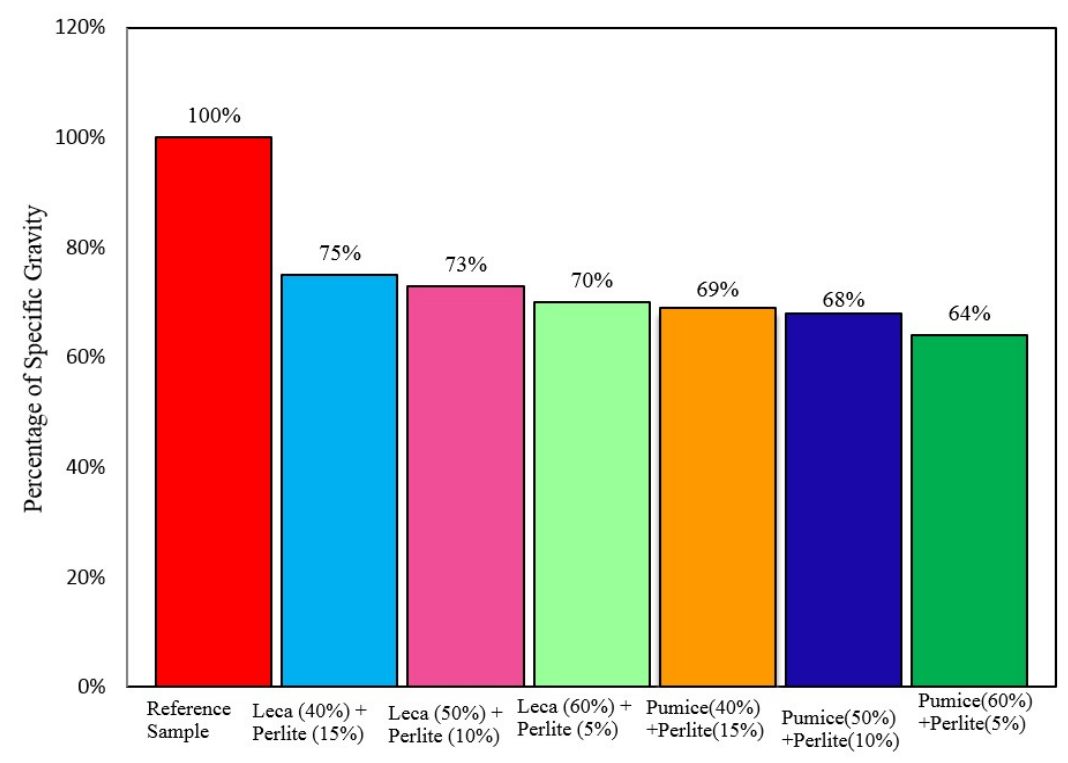

Fig. 16. The shrinkage percentage of specific gravity for the constructed lightweight concrete compared to normal concrete 


\section{CONCLUSION}

In this experimental article, the effects of different percentages of additives (perlite, LECA, and pumice) on the mechanical properties of structural LA concrete was investigated. The results are as follows:

- Specific gravity increased the compressive strength in the experimental samples in lightweight LECA and perlite aggregates. The lowest compressive strength was obtained for models with lightweight perlite and pumice aggregate with a specific gravity of 1450 . The highest compressive strength was obtained for the model with lightweight LECA and perlite aggregates and a specific gravity of 1750 . In addition, increasing the specific gravity resulted in an increase in compressive strength.

- The ratio of compressive strength for 7- to 28-day lightweight concretes is between 0.7 and 0.8 , considering the ratio of tensile strength to compressive strength of normal concrete is about 10 . The ratio for optimal lightweight concretes is between 13.55 and 17.79 , which is related to good indirect tensile strength of the structural lightweight concretes.

- The experiment results indicated that increasing the amount of cement increases the compressive strength. By increasing the cement from 300 to 400 $\mathrm{kg} / \mathrm{m}^{3}$ in mixtures of LECA and perlite for water to cement ratios of $0.3,0.35$, and 0.4 , the strength of the laboratory models increases from 156 to 345 $\mathrm{kg} / \mathrm{cm}^{2}$.

- Regarding the effect of cement on the compressive strength, the compressive strength increased in most of the designs by increasing the amount of cement, which indicated that the amount of cement has a direct effect on increasing the strength regardless of the composition of LAs.

- The compressive strength decreased by increasing the water to cement ratio. In the model with a constant water to cement ratio of 0.3 , a mixture of $40 \%$ LECA and $15 \%$ perlite, the highest compressive strength was obtained for the cement amount of $400 \mathrm{~kg} / \mathrm{m}^{3}$. The compressive strength for this model was $345 \mathrm{~kg} / \mathrm{cm}^{2}$. The minimum compressive strength of $87 \mathrm{~kg} / \mathrm{cm}^{2}$ was obtained for the model with $5 \%$ perlite and $60 \%$ pumice, with the amount of consumed cement being $300 \mathrm{~kg} / \mathrm{m}^{3}$.

- The reduction of strength in concretes with a mixture of pumice and perlite aggregates was more than for LECA and perlite aggregates. The highest compressive strength in lightweight concrete was for $40 \%$ LECA and 15\% perlite in a water to cement ratio of 0.3 and $400 \mathrm{~kg} / \mathrm{m}^{3}$ of cement. The results showed that the compressive strength decreased by $4 \%$ when changing the water to cement ratio from $0.5-0.4$ for a fixed amount of cement $(300 \mathrm{~kg})$. 
- It is possible to achieve structural lightweight concrete with a standard specific gravity by using a combination of lightweight (LECA with perlite) and (pumice with perlite) aggregates in concrete. The results indicated that LECA aggregates have a greater effect on the behavior of concrete.

- The specific gravity of the structural lightweight concrete constructed with a mixture of LECA, pumice, and perlite aggregates can be $25-31 \%$ lighter than ordinary concrete.

- Further, the elastic modulus of the concretes constructed was about (0-8\%) higher than the results of the proposed equation in the standard.

- In addition, the optimal volume of aggregates was between $0.3-0.328$ of the used concrete to obtain structural lightweight concrete containing a mixture of LECA, pumice, and perlite aggregates with appropriate efficiency and strength.

\section{Conflict of Interest}

The authors declare that they have no conflict of interest.

\section{REFERENCES}

1. ACI Committee 211 1998. Standard practice for selecting proportions for structural lightweight concrete (ACI 211.2-98). American Concrete Institute.

2. American concrete institute 2006. ACI committee 318, building code requirements for structural concrete (ACI 318 M-99).

3. ASTM C330 2009. Standard Specification for Lightweight Aggregates for Structural Concrete. Annual book of ASTM standards, ASTM, West Conshohocken, Pennsylvania.

4. Aydın, S and Baradan, B 2007. Effect of pumice and fly ash incorporation on high temperature resistance of cement-based mortars. Cement and Concrete Research 37(6), 988-995.

5. Bogas, JA and Gomes, T 2015. Mechanical and durability behaviour of structural lightweight concrete produced with volcanic scoria. Arabian Journal for Science and Engineering 40(3), 705-717.

6. Bogas, JA, Gomes, MG and Gomes, A 2013. Compressive strength evaluation of structural lightweight concrete by non-destructive ultrasonic pulse velocity method. Ultrasonics 53(5), 962-972.

7. Huang, X, Ranade, R, Zhang, Q, Ni, W and Li, VC 2013. Mechanical and thermal properties of green lightweight engineered cementitious composites. Construction and Building Materials 48, 954-960. 
8. Iranian Concrete Institute,.(2005). Guidelines for Concrete Code of Iran (ABA).

9. Khaloo, AR 1994. Properties of concrete using crushed clinker brick as coarse aggregate. Materials Journal 91(4), 401-407.

10. Khaloo, AR, Dehestani, M and Rahmatabadi, P 2008. Mechanical properties of concrete containing a high volume of tire-rubber particles. Waste management 28(12), 2472-2482.

11. Shafigh, P, Jumaat, MZ, Mahmud, H and Hamid, NAA 2012. Lightweight concrete made from crushed oil palm shell: tensile strength and effect of initial curing on compressive strength. Construct Build Materials 27, 252-258.

12. Zaetang, Y, Wongsa, A, Sata, V and Chindaprasirt, P 2013. Use of lightweight aggregates in pervious concrete. Construction and Building Materials 48, 585-591.

13. Nguyen, LH, Beaucour, AL, Ortola, S and Noumowé, A 2014. Influence of the volume fraction and the nature of fine lightweight aggregates on the thermal and mechanical properties of structural concrete. Construction and building materials 51, 121-132.

14. Salim, S 2020. Fracture and Permeability Properties of Artificial Fly Ash and Slag aggregate Concretes at Different Water-to-Cement Ratios. Journal of Material Science and Technology Research 7, 11-29.

15. Yu, QL, Spiesz, P and Brouwers, HJH 2015. Ultra-lightweight concrete: conceptual design and performance evaluation. Cement and Concrete Composites 61, 18-28.

16. Shafigh, $\mathrm{P}, \mathrm{Chai}, \mathrm{LJ}$, Mahmud, HB and Nomeli, MA 2018. A comparison study of the fresh and hardened properties of normal weight and lightweight aggregate concretes. Journal of building Engineering 15, 252-260.

17. Wongkvanklom, A, Posi, P, Khotsopha, B, Ketmala, C, Pluemsud, N, Lertnimoolchai, S and Chindaprasirt, P 2018. Structural lightweight concrete containing recycled lightweight concrete aggregate. KSCE Journal of Civil Engineering 22(8), 3077-3084.

18. Aghamohammadzadeh, F, Afshin, H and Nekooei, M 2019. Experimental Evaluation of Relationship between Shear Deformation and Pinching in Lightweight-aggregate Reinforced Concrete Beams. KSCE Journal of Civil Engineering 23(1), 173-179.

19. Bogas, JA, Carriço, A and Pontes, J 2019. Influence of cracking on the capillary absorption and carbonation of structural lightweight aggregate concrete. Cement and Concrete Composites 104, 103382. 
20. Tajra, F, Abd Elrahman, M, Lehmann, C AND Stephan, D 2019. Properties of lightweight concrete made with core-shell structured lightweight aggregate. Construction and Building Materials 205, 39-51.

21. Demirel, B, Gultekin, E AND Alyamac, KE 2019. Performance of Structural Lightweight Concrete containing Metakaolin after Elevated Temperature. KSCE Journal of Civil Engineering 23(7), 2997-3004.

22. Regin, JJ, Vincent, P, Shiny, DS AND Porcia, L March 2019 . Neural Network Prediction of Compressive Strength of Lightweight Coconut Shell Concrete. In 2019 International Conference on Recent Advances in Energy-efficient Computing and Communication (ICRAECC). IEEE. 1-7.

23. Yu, QL, Glas, DJ and Brouwers, HJH 2020. Effects of Hydrophobic Expanded Silicate Aggregates on Properties of Structural Lightweight Aggregate Concrete. Journal of Materials in Civil Engineering 32(6), 06020006.

24. Ibrahim, M, Ahmad, A, Barry, MS, Alhems, LM and Suhoothi, AM 2020. Durability of Structural Lightweight Concrete Containing Expanded Perlite Aggregate. International Journal of Concrete Structures and Materials 14(1), 1-15.

25. Sikora, P, Rucinska, T, Stephan, D, Chung, SY and Abd Elrahman, M 2020. Evaluating the effects of nanosilica on the material properties of lightweight and ultra-lightweight concrete using image-based approaches. Construction and Building Materials 264, 120241.

26. Kalpana, M and Tayu, A 2020. Experimental investigation on lightweight concrete added with industrial waste (steel waste). Materials Today: Proceedings 22, 887-889.

27. Shariati, M, Mafipour, MS, Mehrabi, P, Ahmadi, M, Wakil, K, Trung, NT and Toghroli, A 2020. Prediction of concrete strength in presence of furnace slag and fly ash using Hybrid ANN-GA (Artificial Neural Network-Genetic Algorithm). Smart Structures and Systems 25(2), 183195.

28. Oghabi, M, Khoshvatan, M 2020. The Laboratory Experiment of the Effect of Quantity and Length of Plastic Fiber on Compressive Strength and Tensile Resistance of Self-Compacting Concrete, KSCE Journal of Civil Engineering 24(8), 2477-2484

29. Yang, KH 2021. Shear friction response of lightweight concrete using bottom ash aggregates and air foams. Journal of Structural Integrity and Maintenance 6(1), 37-46.

30. Natalli, JF, Xavier, EM, Costa, LCB, Rodrigues, BH, Sarmanho, AMC and Peixoto, RAF 2021. New methodology to analyze the steel-concrete 
bond in CFST filled with lightweight and conventional concrete. Materials and Structures 54(1), 1-12.

Editor received the manuscript: 28.01.2021 